\title{
Inflow and Outflow of Foreign Direct Investments in BRICS Countries - An Analysis
}

\section{Krishna Veni}

Siva Sivani Institute of Management Secunderabad, Telangana, India.

Email:kvenil@gmail.com

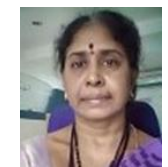

\begin{abstract}
Foreign Direct Investment broadly includes any long-term investments by an entity that is not a resident of the host country. It may be in the form of inflow of FDIs from other countries into the domestic economy or outflow of FDIs from the domestic economy to other countries. Against this backdrop, this study mainly aimed to examine the macroeconomic scenario of all BRICS nations in. It also intends to estimate the growth of the inflow of FDI into BRICS, the outflow of FDI from BRICS during the study period 1998-2018 using Simple Linear Regression and to forecast the inflow and outflow of FDI in immediate future. The results reveal some interesting facts with significant variations in the key macroeconomic variables of BRICS like annual growth of GDP, current account deficit, rate of inflation, unemployment etc. Results reveal that except India, rest of the BRICS countries are deriving more than $50 \%$ of the GDP from the service sector only in 2018. The findings of the study conclude that China has recorded the highest growth in terms of the inflow of FDI among the BRICS during the study period. But. Russian Federation and Brazil have recorded the highest growth rates in terms of the outflow of FDIs from BRICS during the study period .Based on the regression coefficient values, projection of inflow and outflow of FDIs are made, however, the projections will be accurate only when the other things remaining the same.
\end{abstract}

Keywords: BRICS, Inflow of FDI, Outflow of FDI, Emerging economies, Macroeconomic variables, Descriptive statistics, Simple linear equation, Projections.

JEL Classification: E27, E29, F20, F2 1 \& F29.

Citation | L. Krishna Veni (2020). Inflow and Outflow of Foreign Direct Investments in BRICS Countries - An Analysis. Economy, $7(2): 98-103$.

History:

Received: 19 May 2020

Revised: 22 June 2020

Accepted: 27 July 2020

Published: 10 August 2020

Licensed: This work is licensed under a Creative Commons

Attribution 3.0 License (c) $\mathbf{E Y}$

Publisher: Asian Online Journal Publishing Group
Funding: This study received no specific financial support

Competing Interests: The author declares that there are no conflicts of interests regarding the publication of this paper.

Transparency: The author confirms that the manuscript is an honest, accurate, and transparent account of the study was reported; that no vital features of the study have been omitted; and that any discrepancies from the study as planned have been explained.

Ethical: This study follows all ethical practices during writing.

\section{Contents}

1. Introduction

2. Review of Literature

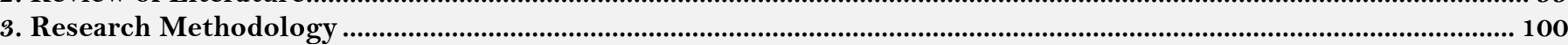

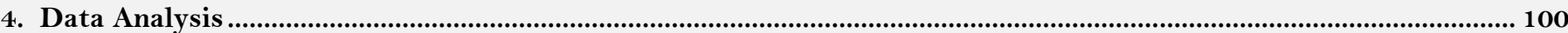

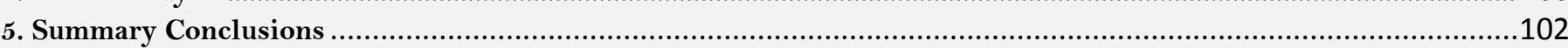

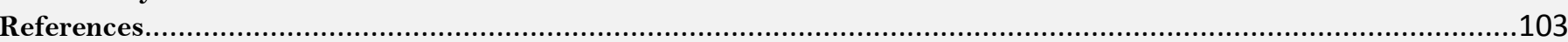




\section{Contribution of this paper to the literature}

This study is important in the following lines. Firstly, the research provides a broad view on recent macroeconomic scenario of BRICS nations to understand the comparative situation. Further, the study attempts to analyse the inflow of FDIs into BRICS and outflow of FDIs from BRICS during a long period of 21 years, hence it will serve as literature for other individuals who are interested to analyse the FDI in both directions of FDI in the immediate future. Finally, the projections made in this study help to the companies and countries to take their business decisions to some extent in immediate future, however the projections are always subjected to economic stability of the BRICS nations.

\section{Introduction}

Foreign direct investments (FDI) are investments made by one company into another company located in another country. Foreign Direct Investments(FDIs) can be classified as Inward/Inflow of FDI and Outward /Outflow of FDI, depending on the direction of the flow of money. The inflow of FDI occurs when foreign capital is invested in local resources. The factors driving the growth of inflow of FDI include availability of inputs or factors of production at a cheaper rate, low tax rates, low interest rates and grants concessions and relaxations from the government of the host countries. Other benefits of Inflow of FDIs include access to superior international technologies, exposure to better management and accounting practices, and improved corporate governance

Outward FDI, also known as direct investment abroad, it means firms in the home country expand its business to other countries in the form of investments in Multinational corporations, mergers or acquisition, etc.

Generally, foreign investors are motivated by profits and access to natural resources available in the host country. Therefore, large and growing domestic markets are likely to receive more FDI. Countries with abundant natural resources such as mines, oil reserves and manpower attract the foreign investors to invest in that country.

In 2001, BRICs countries were originally projected to be the fastest growing market economies by Jim O'Neill of Goldman Sachs. The emerging nations of Brazil, Russia, India, and China (BRICs) believed to be the future leading suppliers of manufactured goods, services, and raw materials by 2050 . China and India will become the world's main suppliers of manufactured goods and services, respectively, while Brazil and Russia will also develop like dominant suppliers of raw materials. South Africa joined the group in the year 2010, which is now referred to as BRICS.

\section{Review of Literature}

Sutirtho (2012) in her study exposes that the responsibility of ushering in a new wave of economic growth has fallen on the shoulders of the BRIC countries. The inward and outward FDIs in any country depends upon many factors. Against this backdrop, this study attempts to compare the FDI trends in BRIC countries over the last 10 years, to analyze the effect of government policies on foreign trade, to establish an understanding of the effect of the economic crisis on the existing FDI patterns of developing countries. Further it attempts to explore the scope for changes in FDI policies of these countries in the future and predicting their possible effects. The authors believe that the analysis of this paper will serve to understand the economic growth paradigms in the BRIC nations and their potentially cascading effects on the future economic sustainability of the planet.

Vinay (2014) in his study analyzed the trend of FDI flow into the country and to find the relation between FDI, Foreign Institutional Investment (FII) and GDP of the country. However, the analysis shows that the country is still far behind compared to countries like China. The continuous increase in FDI, allowed across the industries and sectors, has proven that foreign investors have faith in the resilience of Indian markets. Furthermore, the results indicate that the flow of FDI and GDP are positively correlated with each other and the country's GDP is showing a positive movement with the flow of Foreign Direct Investment in India. The flow of FII and FDI also shows a positive correlation with each other.

Panigrahi and Panda (2012) in their study attempt to find out the factors which are significantly related and influence the FDI inflow into China, India, and Malaysia during the study period 1991 to 2010. Correlation has been used to study the factors influencing FDI inflow. The study revealed that India and China are very similar, whereas in Malaysia the same factors do not influence the inflow of foreign investment to the country. GDP of the country, gross capital formation, capital infrastructure, external debt, export, and import volume are the major factors that significantly influence foreign capital inflow into the two highly populated, fast growing Asian countries, that is, China and India. In the case of Malaysia, only domestic investment or gross domestic capital formation is significantly related to its FDI inflow

Anupam (2014) in his study depicts that over the past few years India's outward foreign direct investment (OFDI) flows and stocks have increased intensely though the immense flow of OFDI from developing countries at an international level is fairly a new phenomenon. This paper analyses the impact of FDI outflows on the GDP of BRICS countries. The authors have applied the regression model that explains that overseas FDI does not show a significant impact on GDP. These countries are trying to make efforts to increase their GDP and FDI but due to some constraints, they are not achieving their targets.

Nandita (2014) attempts to empirically explore the evidence of the macroeconomic relationship between outward foreign direct investment (OFDI) and levels of domestic capital formation in the BRIC economies. The findings of the study reveal that OFDI has both short run and long run positive causality with domestic investment and thus figures out to be a significant factor affecting domestic investment in the BRIC nations. It becomes imperative, thus, that the BRIC countries make a special effort to encourage their OFDI through the designing of proper OFDI policies that would help stimulate heir domestic investment and economic grow throw and in the future.

Wladimir (2016) attempts to compare the study of outward foreign direct investment from BRIC countries and strategies conducted by multinational corporations (MNCs) whose parent companies are based in the BRICs. The focus is on Brazilian and Indian MNCs and their OFDI using as a benchmark major outcomes derived from the study of Chinese and Russian multinationals. To the contrary the intent is to check, against a benchmark of 
MNCs emerging from former centrally planned economies with a single (communist) party regime, how much the differences in Brazilian and Indian market economies with a democratic political regime over the past decades countervail (or not) the assumed similarities across all the BRICs.

Ramar, Prabakaran, Rajendran, and Muthu Kumaran (2019) in their study, elucidate that the FDI plays a predominant role in the improvement of the nation's growth and the global business. This paper gathers evidence through a panel exercise that actual FDI to India during the year 2017-18 fell short of its potential level. An attempt is made in this paper to know the FDI equity inflows from various countries to India. An attempt has been made by the researcher through this paper to examine the economic growth through FDI. For the analysis the statistical tools like one-Way ANOVA, K-S Test has been used and the suggestions and the recommendations are based on the approach.

Vijayalakshmi, Palanisingh, Lingavel, and Gurumoorthy (2019) in their study explained that FDI has become an integral part of national development strategies for almost all the nations globally. FDI in India has contributed effectively to the overall growth of the economy in recent times. The main objective of the study is to identify the factors determining in foreign direct investment in India. The data mainly based on secondary data. The collected data were analysed by using trend analysis and growth rate of the top ten sectors in India. This study also found that FDI in India has contributed effectively to the overall growth of the economy in the recent times. Thus, India can grow without FDI and in fact developed without or with very little FDI. Developing countries like India need substantial foreign inflows to achieve the required investment to accelerate economic growth and development.

From the above review it is clear that most of the studies have confined to a short period (10 - 15 years) only and focussed either on the inflow of FDIs in BRICS countries or outflow of FDIs from FDIs. However, this study tries to analyse the inflow and outflow of FDIs of BRICS nations with the following objectives:

1. To examine the macroeconomic scenario of all BRICS Nations.

2. To estimate the growth of the inflow of FDI into BRICS countries during the study period and to forecast the inflow of FDI in immediate future.

3. To estimate the growth of the outflow of FDI from BRICS countries during the study period and to forecast the inflow of FDI in immediate future.

\section{Research Methodology}

The sample selected for this study are five emerging economies viz., Brazil, Russia Federation, India, China, and South Africa, which are popularly known as BRICS. The present study is exclusively based on secondary data and mainly it is carried out to examine the inflow of FDIs into BRICS nations and outflow of FDIs from BRICS nations. The data on inflow and outflow of FDIs required for this study has been drawn from www.unctad.org and the data on macroeconomic variables of BRICS has been collected from https://globaledge.msu.edu/globalinsights/by/country.

The inflow of FDI and outflow of FDI are considered in terms of US $\$$ at current prices in millions for 21 years i.e., from 1998-2018.

Descriptive statistics, Simple Linear regression $(\mathrm{Y}=\mathrm{a}+\mathrm{bx})$, and forecasting Technique based on regression coefficient(b) have been applied to analyse the data with the help of SPSS. The forecasts generated by Simple Linear Regression method show a constant trend either increasing or decreasing indefinitely into the future.

\section{Data Analysis}

Initially the macro economic variables of BRICS in 2018 are compared across the BRICS nations to understand the comparative scenario in Table1A.

Table-1A. Rank in GDP out of 196 Countries \& among BRICS in 2018.

\begin{tabular}{|c|c|c|}
\hline Country & Rank in GDP out of 196 countries in 2018 & Rank among BRICS \\
\hline Brazil & 7 & 4 \\
\hline Russian Federation & 6 & 3 \\
\hline India & 3 & 2 \\
\hline China & 2 & 1 \\
\hline South Africa & 29 & 5 \\
\hline
\end{tabular}

GDP is the most important macroeconomic indicator to understand the economic growth of any economy. Table1A explains the ranks of GDP relating to the BRICS nations out of 156 countries considered in 2018 by globaledge.msu.edu. China(2nd), India(3rd), Russian Federation(6th), Brazil(7th), and South Africa(29th) ranks in the world (196 countries). However, in the same order, these countries have occupied the rank between Ist to 5 th positions among BRICS in 2018.

The Macroeconomic Variables of BRICS in 2018 are represented in Table1B. It reveals some interesting facts with significant variations in some of the macroeconomic variables of BRICS. All countries of BRICS are known as developing economies only except Soviet Russia, which is the only High Income country which is in transition. Being a Lower Middle Income country among BRICS, India recorded significant annual growth of GDP with $6.81 \%$ in the year 2018. 2nd place has been occupied by the Upper Middle Income country China(6.57\%), whereas South Africa(0.79\%) remained in the bottom position, though it is a Upper Middle Income country. In terms of per capita income(PPP) Russia and China occupied the $1^{\text {st }}$ and 2 nd places. China has the highest external debt stock among the BRICS countries. India, Brazil, and South Africa have shown a deficit in their current account balance, whereas the remaining countries of BRICS like Soviet Russia and China have shown surplus. The rate of inflation is more than $4 \%$ in India and South Africa but in China, it is 2.01\% only in the year 2018. Labour force has shown high figures in both highly populous countries like China and India. It is disappointing to note that the rate of unemployment is very high in South Africa(28.18\%) and Brazil (12.07) among the BRICS in 2019. In value of goods and services of imports and exports also China maintained its supremacy among the BRICS. 
Table-1B. Macroeconomic variables of BRICS in 2018.

\begin{tabular}{|c|c|c|c|c|c|}
\hline Factor & Brazil & Russia & India & China & South Africa \\
\hline Income Level (by per capita GNI) & UMI & HI & LMI & UMI & UMI \\
\hline Level of Development: & Developing & In Transition & Developing & Developing & Developing \\
\hline GDP, PPP(current international\$) & $\$ 3,371.80 \mathrm{~b}$ & $\$ 4,050.79 b$ & $\$ 10,500.21 \mathrm{~b}$ & $\$ 25,398.68 b$ & $\$ 790.82 b$ \\
\hline GDP growth (annual \%) & $1.12 \%$ & $2.25 \%$ & $6.81 \%$ & $6.57 \%$ & $0.79 \%$ \\
\hline $\begin{array}{l}\text { GDP per capita, PPP } \\
\text { (current international } \$\end{array}$ & $\$ 16,096.40$ & $\$ 27,143.33$ & $\$ 7,762.88$ & $\$ 18,236.61$ & $\$ 13,686.88$ \\
\hline $\begin{array}{l}\text { External debt stocks, total } \\
\text { (DOD, current US\$) }\end{array}$ & $\begin{array}{l}\$ 557,822, \\
647,211.20 \\
\end{array}$ & $\begin{array}{l}\$ 453,938, \\
114,126.20\end{array}$ & $\begin{array}{l}\$ 521,390, \\
564,017.40\end{array}$ & $\begin{array}{l}\$ 1,962,304 \\
426,779.10\end{array}$ & $\begin{array}{l}\$ 179,306, \\
413,801.80\end{array}$ \\
\hline $\begin{array}{l}\text { Current account balance (BoP, } \\
\text { current US } \$ \text { ) }\end{array}$ & $*_{-\$ 41.54 b}$ & $\$ 113.45 \mathrm{~b}$ & *-\$65.60b & $\$ 49.0 b$ & $*-\$ 13.38 b$ \\
\hline $\begin{array}{l}\text { Inflation, consumer prices } \\
\text { (annual \%) }\end{array}$ & $3.66 \%$ & $2.88 \%$ & $4.86 \%$ & $2.07 \%$ & $4.50 \%$ \\
\hline Labor force, total (2019) & $\begin{array}{c}10,63,28 \\
664 \\
\end{array}$ & $7,27,36,316$ & $\begin{array}{l}51,94,69 \\
299 \\
\end{array}$ & $78,31,94,000$ & $2,30,72,331$ \\
\hline $\begin{array}{l}\text { Unemployment, total (\% of total } \\
\text { labour force)ILO estimate) (2019) }\end{array}$ & $12.08 \%$ & $4.58 \%$ & $5.35 \%$ & $4.32 \%$ & $28.18 \%$ \\
\hline $\begin{array}{l}\text { Imports of goods and services } \\
\text { (current US } \$ \text { ) }\end{array}$ & $\$ 266.78 b$ & $\$ 344.26 \mathrm{~b}$ & $\$ 642.7 \mathrm{ob}$ & $\$ 2,548.99 \mathrm{~b}$ & $\$ 108.88 \mathrm{~b}$ \\
\hline $\begin{array}{l}\text { Exports of goods and services } \\
\text { (current US } \$ \text { ) }\end{array}$ & $\$ 276.66 \mathrm{~b}$ & $\$ 509.55 \mathrm{~b}$ & $\$ 536.62 \mathrm{~b}$ & $\$ 2,655.61 \mathrm{~b}$ & $\$ 110.14 b$ \\
\hline
\end{tabular}

Note: *Represents Deficit, b- Billions, UMI-Upper Middle Income, HI-High Income\& LMI-Lower Middle Income.

Table-2.Composition of GDP in BRICS Nations -(\%) in 2018.

\begin{tabular}{c|c|c|c|c}
\hline Country & Agriculture & Services & Industry & Manufacturing \\
\hline Brazil & 4.42 & 63.02 & 18.13 & 9.78 \\
\hline Russian Federation & 3.15 & 54.12 & 32.07 & 13.31 \\
\hline India & 14.6 & 45.13 & 26.75 & 14.82 \\
\hline China & 7.19 & 52.16 & 40.65 & 29.41 \\
\hline South Africa & 2.18 & 64.04 & 25.85 & 11.76 \\
\hline
\end{tabular}

The composition of GDP (\%) may exceed 100 also. Manufacturing is included in the industry figures and in also reported separately since it plays a vital role in many of the countries in the world including BRICS. Table 2 reveals that except India, rest of the BRICS countries are deriving more than $50 \%$ of the GDP from the service sector only in 2018. However, South Africa and Brazil occupied the first and second places with more than $60 \%$ contribution from service sector to GDP. China (40.65\%) and Russian Federation $(32.15 \%)$ have contributed significant share from the industrial sector. In the manufacturing sector, China is the only country that contributed $29.41 \%$ to GDP in 2018. In the agriculture sector India is the only country that contributes more to GDP with a double digit figure $(14.6 \%)$.

Table-3. Descriptive Statistics of Inflow of FDIs in BRICS-1998-2018(21 years).

\begin{tabular}{c|c|c|c|c|c}
\hline Country & $\mathbf{N}$ & Minimum & Maximum & Mean & Std. Deviation \\
\hline Brazil & 21 & 10143.525 & 97421.786 & 43247.856 & 25016.532 \\
\hline Russian Federation & 21 & 2651.06 & 75855.697 & 24622.303 & 20079.378 \\
\hline India & 21 & 2168 & 47102.417 & 23188.095 & 16412.998 \\
\hline China & 21 & 40318.71 & 139043.492 & 91754.362 & 36722.953 \\
\hline South Africa & 21 & 311.4501 & 9209.172 & 3850.3717 & 2867.605 \\
\hline
\end{tabular}

From the descriptive statistics as shown in Table 3, it is clear that China recorded a maximum inflow of FDI during the study period. Brazil, Russia, India, and South Africa have occupied the 2nd, 3rd,4th, and 5th places during the same period of 21 years. China is recorded huge inflows of FDI when compared with other BRICS nations in all the countries. A similar picture can be noticed from the mean values during the study period.

Table-4. Inflow of FDIs in BRICS-simple linear regression equations.

\begin{tabular}{c|c}
\hline Country & Regression Equation $(\mathbf{Y}=\mathbf{a}+\mathbf{b x})$ \\
\hline Brazil & $\mathrm{Y}=12334.099+2810.342 \mathrm{x}$ \\
\hline Russian Federation & $\mathrm{Y}=8659.280+1454.820 \mathrm{x}$ \\
\hline India & $\mathrm{Y}=-2673.937+2351.094 \mathrm{x}$ \\
\hline China & $\mathrm{Y}=28279.790+5770.416 \mathrm{x}$ \\
\hline South Africa & $\mathrm{Y}=2334.059+137.847 \mathrm{x}$ \\
\hline
\end{tabular}

From Table 4 it is clear that the coefficient value of China has shown the highest value (5770.416), which reflects the high growth of FDI among the BRICS countries during the study period. Brazil (2810.342), India (2351.094), Russian Federation (1454.820), and South Africa(137.847) have recorded the values of the coefficients (growth rates) in the ascending order. 
Table-5. Projections of Inflow of FDI in BRICS (2019-2023)

\begin{tabular}{|c|c|c|c|c|c|}
\hline Country & 2019 & 2020 & 2021 & 2022 & 2023 \\
\hline Brazil & 74161.6 & 76971.96 & 79782.31 & 82592.649 & 85402.99 \\
\hline Russian Federation & 40665.3 & 42120.14 & 43574.96 & 45029.78 & 46484.6 \\
\hline India & 49050.1 & 51401.22 & 53752.32 & 56103.413 & 58454.507 \\
\hline China & 155229 & 160999.36 & 166769.77 & 172540.19 & 178310.61 \\
\hline South Africa & 5366.69 & 5504.54 & 5642.39 & 5780.23 & 5918.08 \\
\hline
\end{tabular}

Based on the Regression equations from Table 4, the inflow of FDI has been forecasted for the estimated 5 years that is from 2019 to 2023. It can be inferred that estimated projections as shown in Table 5 that the inflow of FDI has shown the highest figure in China in all five years. The second place has been occupied by Brazil. India Soviet Russia remained in the 3rd and the 4th positions in all projected years.. But South Africa remained in the bottom position since it has entered BRICS in the year 2010 only as the emerging economy.

Table-6. Descriptive Statistics of Outflow of FDIs from BRICS -1998-2018.

\begin{tabular}{c|c|c|c|c|c}
\hline Country & N & Minimum & Maximum & Mean & Std. Deviation \\
\hline Brazil & 21 & 13036 & 28202.5 & 3630.71 & 11072.30 \\
\hline Russian Federation & 21 & 915.77 & 196149 & 61147 & 61433.51 \\
\hline India, & 21 & 47 & 21142.5 & 7840.29 & 6668.55 \\
\hline China & 21 & 1209.75 & 70684.8 & 28337 & 21078.52 \\
\hline South Africa & 21 & -3177.9 & 7669.46 & 2336.05 & 3171.11 \\
\hline
\end{tabular}

Table 6 reveals that the descriptive statistics relating to outflow of FDIs from BRICS countries during the study period. Russian Federation (61147), China(28337), India(7840.29), Brazil(3630.71), and South Africa(2336.05) have shown the mean values in the ascending order during the study period.

Table-7. Outflow of FDIs from BRICS- simple linear regression equations.

\begin{tabular}{c|c}
\hline Country & Regression Equation $(\mathrm{Y}=\mathrm{a}+\mathrm{bx})$ \\
\hline Brazil & $\mathrm{Y}=7095.84+315.01 \mathrm{x}$ \\
\hline Russian Federation & $\mathrm{Y}=2946.63+2390.03 \mathrm{x}$ \\
\hline India & $\mathrm{Y}=535+43 \mathrm{x}$ \\
\hline China & $\mathrm{Y}=9235+42 \mathrm{x}$ \\
\hline South Africa & $\mathrm{Y}=1156+31 \mathrm{x}$ \\
\hline
\end{tabular}

From the regression equations, as shown in Table 7, it is clear that Russian Federation(2390.03) and Brazil(315.01) have shown highest coefficient values (growth rates) relating to the outflow of FDIs from BRICS during the study period, whereas the other countries of BRICS like India (43), China(42) and South Africa(31) have recorded lesser growth rates.

Table-8. Projections of Outflow of FDI from BRICS (2019-2023).

\begin{tabular}{c|c|c|c|c|c}
\hline Country & $\mathbf{2 0 1 9}$ & $\mathbf{2 0 2 0}$ & $\mathbf{2 0 2 1}$ & $\mathbf{2 0 2 2}$ & $\mathbf{2 0 2 3}$ \\
\hline Brazil & 14026.1 & 14341.1 & 14656.1 & 14971.1 & 15286.1 \\
\hline Russian Federation & 55527.3 & 57917.3 & 60307.4 & 62697.4 & 65087.4 \\
\hline India & 1481 & 1524 & 1567 & 1610 & 1653 \\
\hline China & 10159 & 10201 & 10243 & 10285 & 10327 \\
\hline South Africa & 1838 & 1869 & 1900 & 1931 & 1962 \\
\hline
\end{tabular}

Based on the regression equations from Table 7 the outflow of FDI from BRICS has been forecasted for the estimated 5 years that is from 2019 to 2023. From Table 8, it can be inferred that estimated projections relating to the outflow of FDI have shown highest amount from Russian Federation. Second place has been occupied by Brazil. China remained in third place and South Africa maintained fourth position for all years from 2019 to 2023 as per the projections. But India remained in the least position since it has focused only on inflow of FDIs and boosting the domestic investments.

\section{Summary Conclusions}

The results of this study reveal some interesting facts with important distinctions in some of the macroeconomic variables of BRICS.GDP as the most important macroeconomic indicator of economic growth, China, India Russian Federation, Brazil, and South Africa have occupied the rank between Ist to 5th positions among BRICS in 2018.

India being a Lower Middle-Income country recorded significant annual growth of GDP with $6.81 \%$ in the year 2018. 2nd place has been occupied by the Upper Middle-Income country China (6.57\%) among BRICS. India, Brazil, and South Africa have shown current account deficit, whereas the remaining countries of BRICS have shown surplus. The rate of inflation is more than $4 \%$ in India and South Africa but rest of the countries, it is around $2 \%$ only. In both highly populous countries like China and India, the labor force has shown high figures. The rate of unemployment is very high in South Africa (28.18\%) and Brazil (12.07) among the BRICS countries in 2019. China maintained its supremacy among the BRICS in terms of the value of goods and services of imports and exports also. It is clear that except India, the rest of the BRICS countries are deriving more than $50 \%$ of the GDP from the service sector only in 2018, however, South Africa and Brazil occupied the first and second places with more than $60 \%$ contribution to GDP. China (40.65\%) and Russian Federation $(32.15 \%)$ have contributed 
significant share from the industrial sector. In the manufacturing sector, China is the only country that contributed $29.41 \%$ to GDP in 2018. Compared to other countries of BRICS. India is the only country that contributes more to GDP with $14.6 \%$ in the agriculture sector.

The findings of the study conclude that China has recorded the highest growth in terms of the inflow of FDI among the BRICS during the study period. Brazil, India, Russian Federation, and South Africa have recorded the values of the coefficients (growth rates) in the ascending order during the study period.

But. Russian Federation and Brazil have recorded the highest growth rates in terms of the outflow of FDIs from BRICS during the study period.

Brazil. China remained in second and third places whereas South Africa maintained the fourth position for all years from 2019 to 2023 as per the projections. India remained in the least position since it has focussed only on the inflow of FDIs and boosting the domestic investments.

Based on the regression coefficient values, projection of inflow and outflow of FDIs are also made in this study, however, the projections will be accurate only when the other things remaining the same.

\section{References}

Anupam. (2014). Impact of FDI outflows on GDP of BRICS countries. Indian Journal of Applied Research, 4(10), 115-116.

Nandita, D. (2014). Home country effect of FDI outflows from the BRIC countries: Study of domestic investment. University of Maryland, Baltimore Country. 1-33. Retrieved from: https://economics.umbc.edu/files/2014/2009/wp_2015_2001.pdf.

Panigrahi, T., \& Panda, B. (2012). Factors influencing FDI inflow to India, China and Malaysia: An empirical analysis. Asia-Pacific Journal of Management Research and Innovation, 8(2), 89-100. Available at: https://doi.org/10.1177/2319510x1200800202.

Ramar, N., Prabakaran, V., Rajendran, S., \& Muthu Kumaran, C. K. (2019). FDI in India: Leading to economic growth. International Journal of Recent Technology and Engineering, 8(2S10), 182-186. Available at: https://doi.org/10.35940/ijrte.b1031.0982s 1019.

Sutirtho, N. (2012). International conference on emerging economies - prospects and challenges comparative analysis of foreign direct investment trends in emerging economies. Procedia, Social and Behavioural Sciences, 7, 230 - 240.

Vijayalakshmi, R., Palanisingh, V., Lingavel, G., \& Gurumoorthy, T. R. (2019). Factors determining in foreign direct investment in India. International Journal of Recent Technology and Engineering, 8(2S10), 722-729. Available at: https://doi.org/10.35940/ijrte.b1 129.0982s 1019.

Vinay, K. (2014). Trend of FDI in India and its impact on economic growth. International Journal of Science and Research, 3(10), 639-642.

Wladimir, A. (2016). Outward foreign direct investment by Brazilian and Indian multinational companies: Comparison with russian-chinese multinationals. Hindustan Aeronautics Limited. 1-45. Retrieved from: https://halshs.archives-ouvertes.fr/halshs01279896/document. 